\title{
Impact of Sedimentation on Water Seepage Capacity in Lake Nakuru, Kenya
}

\author{
Parfait Iradukunda $\mathbb{D}^{1}$ and Maurice O. Nyadawa ${ }^{2}$ \\ ${ }^{1}$ Department of Civil Engineering, Pan African University, Institute for Basic Sciences Technology and Innovation (PAUSTI), \\ P.O. Box 62000-00200, Nairobi, Kenya \\ ${ }^{2}$ School of Engineering and Technology, Jaramogi Oginga Odinga University of Science and Technology (JOOUST), \\ P.O. Box 210-40601, Bondo, Kenya
}

Correspondence should be addressed to Parfait Iradukunda; mugemalixparfait@gmail.com

Received 5 July 2020; Revised 29 January 2021; Accepted 5 February 2021; Published 16 February 2021

Academic Editor: Fedor Lisetskii

Copyright (@ 2021 Parfait Iradukunda and Maurice O. Nyadawa. This is an open access article distributed under the Creative Commons Attribution License, which permits unrestricted use, distribution, and reproduction in any medium, provided the original work is properly cited.

\begin{abstract}
Accumulation and deposition of sediments in waterbody affect the seepage capacity that could lead to improper water balance and results in the water level rise. This study analysed the influence of sedimentation on seepage capacity in Lake Nakuru and the impact of sediment characteristics to the water seepage and the flow rate formation at the lake bed level. The study was performed by sampling and analysing the sediment cores from two locations in the lake. The sediment hydraulic properties, i.e., moisture and porosity, particle sizes, and hydraulic conductivity, were determined using the oven-drying method, sieve analysis, hydrometer analysis, and falling head tests, respectively. The results showed that the lake sediment sample from location P1 had an average ratio of $39.38 \%$ for silty soil, $34.00 \%$ for clayey sediment, and $26.63 \%$ for fine-sand sediment particles with the maximum permeability coefficient of $3.37 * 10^{-5} \mathrm{~cm} / \mathrm{s}$, while the one from location P2 had an average ratio of $63.17 \%$ for sand, $20.17 \%$ for fine particles, and $16.67 \%$ for gravels with the maximum permeability coefficient of $0.010793 \mathrm{~cm} / \mathrm{s}$. The hydraulic conductivity of sediment sample from location P1 and P2 increased along the core depth. This could lead to the rise of water level due to the decreases of water movement induced from the sediment cementation in the top layers under the waterbody. Sedimentation affects Lake Nakuru water volume and water balance; hence, there is a need to control the inflow of sediment resulting from anthropogenic activities in the watershed.
\end{abstract}

\section{Introduction}

Sedimentation is a major environmental threat to sustainability and related water resource efficiencies [1]. Accumulation and deposition of sediment in the lakes and reservoir is a concerning factor threatens their functionality [2-4]. It has been recognized as a major problem in the lakes and the use of surface water supplies [5]. One such lake that could be impacted by sedimentation on water seepage is Lake Nakuru. The sedimentation issue in Lake Nakuru was reported since the past 2 decades [6]. The different hydraulic properties of deposited sediment affect water level and the lake water balance through their ability to allow or prevent the water seepage in the Rift Valley lakes [7]. When high or low rainfall and runoff cause a rapid rise or loss in lake level, the rate of groundwater seepage could increase or diminish due to the difference in elevation head, causing the water level in the lake to rise or dry up [8]. Groundwater acts as a reservoir from which water seeps into or out of the lake through the lakebed sediments $[7,9]$. Lake Nakuru water inputs comprise of direct rainfall over the lake's surface area, surface runoff, and groundwater inflow. No considerable outlet rivers are draining from Lake Nakuru and some neighbouring lakes in Kenya Rift valley. The water is balanced by underground outflow and evaporation [9-12]. The major surface water discharge into Lake Nakuru include several rivers, spring perennial rainfall, sewage plant effluent, and groundwater recharge $[13,14]$. River Njoro is the main source of the sediment delivered in Lake Nakuru with $70 \%$, followed by Makalia 
with $21 \%$, Nderit with $4 \%$, sewage drain (effluents) with $4 \%$, and Baharini with $1 \%$ [6].

The Kenyan rift valley lakes present the groundwater links between them [8]. A series of lakes in the rift valley, Kenya, are fed of rivers and springs engendering the water balance, and the regional groundwater flow systems within Lake Nakuru, Naivasha, Elementeita, Bogoria, and Lake Magadi $[8,9,11,12]$. Due to the lake's sediment hydraulic properties, the groundwater seepage can be the dominant source of water in dry periods and use to stabilize lake levels in those drought periods $[7,8]$.

Lake Nakuru has been fluctuating since the past 4 decades [13, 15]. According to the studies [16-21] conducted from 1972 to 1985 , the lake maximum water depth varied from $2.18 \mathrm{~m}$ to $4.18 \mathrm{~m}$ [21]. The lake depth changed more than $47.8 \%$ in the total period of the research study. This is simply implying a predominant fluctuation of Lake Nakuru water level possibly resulted from unfair water balance linked to climate change and subsurface seepage [22, 23]. According to Vareschi (1982) [18], the lake Nakuru had been almost fully dried up several times during the past 50 years for unknown reasons. During 1995, 1996, and 1997, the lake partially dried up again, resulted in disappearance of most birds and tourism greatly reduced $[7,24]$. The lake levels rebounded over heavy rainfall-driven flooding in 1998, and few flamingoes started returning early 2000 [7]. Since year 2013, Lake Nakuru has been swelling up and submerging the buildings around the lake [15].

The impacts of sediment hydraulic properties on the rise of water level in Lake Nakuru were reported by Jenkins et al. [7]. The water rise in the lake could be resulted from sediment accumulation in the lake. Inappropriate land use and the waste disposal in the watershed are responsible for sedimentation status in Lake Nakuru [7].

Thus, this study sought to understand the impact of sedimentation on water seepage capacity and water level rise in Lake Nakuru. The study used experimental laboratory works to analyse the influence of sedimentation on water balance in the lake and the impact of deposited sediment characteristics to the water seepage capacity.

\section{Materials and Methods}

2.1. Description of the Study Area. Lake Nakuru is located at $00^{\circ} 18^{\prime} 23^{\prime \prime} \mathrm{S}$ to $00^{\circ} 24^{\prime} 48^{\prime \prime} \mathrm{S}$ and $36^{\circ} 03^{\prime} 21^{\prime \prime} \mathrm{E}$ to $36^{\circ} 07^{\prime} 13^{\prime \prime} \mathrm{E}$ (latitude, longitude) in Nakuru County, Kenya (Figure 1). This is a closed basin without outlets in the Kenyan Rift Valley region $[25,26]$. It is included in the Lake NaivashaElmentaita-Nakuru basin, a region where the eastern rift valley attains its highest elevation $[13,25]$. Lake Nakuru is at an elevation of $1,759 \mathrm{~m}$ above sea level. The basin mean annual rainfall and evaporation within the basin is $1060 \mathrm{~mm}$ and $1292 \mathrm{~mm}$, respectively. Further, the mean lake temperature ranges from $20.6^{\circ} \mathrm{C}$ to $23.5^{\circ} \mathrm{C}[15,21]$. According to $[25,26]$, poor waste disposal and anthropogenic influences in the watershed result in the sediment accumulation in the lake.
2.2. Sediment Core Sampling and Processing. Sediment cores were collected at 2 locations as shown in Figure 1, and their geographic location is presented in Table 1. One of the cores was collected in the middle part of the lake while the other one focused towards the entry of River Njoro. According to [6], River Njoro is a major sediment contributor in Lake Nakuru.

During sediment core collection, a vibracoring system which consisted of a high frequency vibrating head and modular weighty rig attached of core tube was used in collecting the sediment cores. The Hex Nut Bolt was used to fix the core tube to the disk. The vibracoring system attached to the coring tube was vertically sunk to the lakebed level using a winch [27-29]. The halt in movement could occur because of sediment tube fully filled or reached the very compacted layer. The core was then retrieved using a winch capped and transported in the vertical position to maintain the sample in its relatively undisturbed state [27, 29].

In the laboratory, the sediment cores were divided into two longitudinally. While the core section is still intact, general visual analysis and description of the sediment core were undertaken considering different colours, texture, and consistency. A similar procedure of processing sediment core had previously been followed by [27]. Subsampling of identified sediment layers along the core (discarding the sediment at core tube walls) was then undertaken as described in [30]. At this point, nonsediment objects such as bottle caps, broken glass, sticks, and large rocks were removed from the sample [27, 31, 32]. The sediment was subsampled in each $5 \mathrm{~cm}$ interval range for moisture analysis and hydraulic conductivity analysis and $10 \mathrm{~cm}$ for particle size analysis.

\subsection{Sediment Hydraulic Properties}

2.3.1. Sediment Moisture and Porosity. The analysis of moisture and porosity was conducted on the sediment samples from location P1 and P2 (Figure 1). The procedure for water content was determined based only to the weight of the soil sample in moist and dry states following the ASTM D2216 as described in $[33,34]$. The amount of water content in the sediment depends on the pore space. Hence, void ratio and porosity of sediment sample were determined based on the weight and volume of sediment sample in moist and dry states considering their respective specific gravity as described in [33-35].

2.3.2. Particle Size Analysis. On sediment samples, particle size analysis (sieve and hydrometer analyses) was undertaken to determine their texture. In this, sieve analysis was undertaken to aid in understanding particle size distribution of the coarse grain sediments (sand and gravel), while hydrometer analysis was done provided a particle size distribution for the fine-grain sediments (silt and clay).

Wet sieve analysis was conducted on sediment sample from location P2 since it had been observed to have abundance of large particles (sands and gravels). In this sample, subsampling had been at $10 \mathrm{~cm}$ interval from top to bottom of 
the sediment core. The sieve analysis procedure was done following the ASTM D421 standard [33, 34].

The coefficient of gradation $C_{U}$ and coefficient of curvature $C_{C}$ referred to as the parameter which indicates the range of distribution of grain sizes in a given soil specimen were established as described in the ASTM D421 standard. In this, particle diameters $D_{10}, D_{30}$, and $D_{60}$ of percentage finer $10 \%, 30 \%$, and $60 \%$ were used to determine the uniformity coefficient $\left(C_{U}\right)$ and the coefficient of gradation $\left(C_{C}\right)$.

The hydrometer analysis was used to determine the finegrained particle size distributions for the fraction finer than No. $200(0.075 \mathrm{~mm})$ from the sediment core. The analysis was done following the ASTM D422 standard [33, 34], from the fine-grained particles that existed in location P1 of the study area. Fresh sediment equivalent to $50 \mathrm{~g}$ dried samples collected at $10 \mathrm{~cm}$ interval along the sediment cores were used for hydrometer analysis.

The subsample was measured and mixed with $125 \mathrm{ml}$ of $4 \%$ sodium hexametaphosphate solution equivalent to $40 \mathrm{~g}$ of Calgon in $1000 \mathrm{ml}$. The solution was flushed into a $1000 \mathrm{ml}$ glass cylinder, which was filled to the $825 \mathrm{ml}$ mark with deionized water and then mixed for two minutes. The hydrometer was then inserted into the glass cylinder. This time was recorded as $t=0$. The hydrometer readings were taken from $0.25,0.5,1,2,4,8,15,30,45,60,75$, and 90 minutes after the initial mixing of the sample and deflocculating solution. Addition readings were taken at 24 and 48 hours.

The analysis was conducted using standard for hydrometer analysis described in $[33,34]$. The percentage of fine material was then calculated using equation (1) as presented in [34]:

$$
\mathbf{P}_{\mathbf{f}}=\frac{a * R_{c p}}{W_{S}} * 100
$$

where $\mathbf{R}_{\mathbf{c p}}$ is the hydrometer correction value, $\mathbf{W}_{\mathbf{s}}$ is the weight of dry soil taken for the test, ais the correction for particle density, and $\mathbf{P}_{\mathbf{f}}$ is the percentage finer value.

2.3.3. Hydraulic Conductivity. To determine flow rate of water through the sediment, hydraulic conductivity was undertaken. This followed the ASTM D5084-10 Deleted standard described in [36]. Both the sediment sample from locations P1 and P2 (Figure 1 and Table 1) were analysed for hydraulic conductivity. The sediment subsamples were taken at an interval of $5 \mathrm{~cm}$ along the sediment core. The procedure for collecting undisturbed soil sample with the tube sampler was done following ASTM D1587 standard [33].

During hydraulic conductivity analysis, the falling head permeability test was used as it is more suitable for finegrained soil, whereas the constant head permeability test is suitable for the coarse-grained soil. Three to four trials were conducted on each sample to get the average coefficient of permeability. Since the velocity of water in the sediment sample was slow, the flow of water was considered as laminar. As a result, the flow rate of water through the sediment specimen of gross cross-sectional area $(A)$ is expressed in equation (2) by Darcy law and the permeability coefficient at the standard temperature was determined using equation (3) described in [33, 34, 37, 38]:

$$
\begin{aligned}
\mathbf{V} & =K i, \\
\mathbf{K}_{20^{\circ} \mathrm{C}} & =K_{T^{\circ} \mathrm{C}} * \frac{\eta_{T^{\circ} \mathrm{C}}}{\eta_{20^{\circ} \mathrm{C}}},
\end{aligned}
$$

where $\mathbf{K}$ is the coefficient of permeability, $\mathbf{i}$ is the hydraulic gradient, $\mathbf{K}_{T^{\circ} \mathrm{C}}$ is the measured permeability coefficient at the actual water temperature $T^{\circ} \mathrm{C}$ in the lab, $\mathbf{K}_{20^{\circ} \mathrm{C}}$ is the permeability coefficient at the standard temperature of $20^{\circ} \mathrm{C}$, $\eta_{T^{\circ} \mathrm{C}}$ is the measured viscosity of water in the lab, at the actual water temperature $\mathrm{T}^{\circ} \mathrm{C}$, and $\eta_{2^{\circ}{ }^{\circ} \mathrm{C}}$ is the viscosity at the standard temperature of water at $20^{\circ} \mathrm{C}$ (standard).

\section{Results and Discussion}

3.1. Sediment Moisture and Porosity. The sediments from location P1 were found to have a high moisture content. It was observed that water content at the top of the core was found to be more than $800 \%$. This can be attributed to high presence of fine particles at the top of sediment core. It was observed that the moisture decreased along the sediment core up to about $300 \%$ at the bottom. On the other hand, water content of sediment from location P2 was found to be less than $80 \%$ (Figure 2). Considering porosity which usually refers to how many pores or holes the sediment has, it was observed that the finer particle size, the greater the moisture and porosity.

According to $[35,39,40]$, water infiltration depends on the degree of saturation or the moisture content in the soil. As a consequence, the soil permeability increases as the degree of saturation decreases and infiltration is likely to stop at a full saturation state. Then, the greater is the porosity, the lesser the soil could be permeable. The properties of sediments with high porosity tend to form rocks with the particles of the same characteristics $[35,39]$.

\subsection{Sediment Particle Size Analysis}

3.2.1. Sediment Sieve Analysis. The lake sediment from location P2 had an average ratio of $63.17 \%$ for sand, $20.17 \%$ for fine particles, and $16.67 \%$ for gravels. Only sand and gravels had $80 \%$ of the whole sediment sample resulting in a large pore space (Figures 3 and 4 ). The shape and size of the soil particles affect the way particles are packed together and fill the pore space contained in the soil, which affects the soil porosity. It was observed that the top of the sediment core was characterized by sand and fine particles at large, while the bottom of the core had sand and gravels at large. The fineness of particles decreases top to bottom of the core. This would result in the low permeability in the top layer compared to the bottom sediment layer. From the particle size analysis, it was observed that the sediments in Lake Nakuru could affect the water movement as the sediment keeps on filling in the lake. 


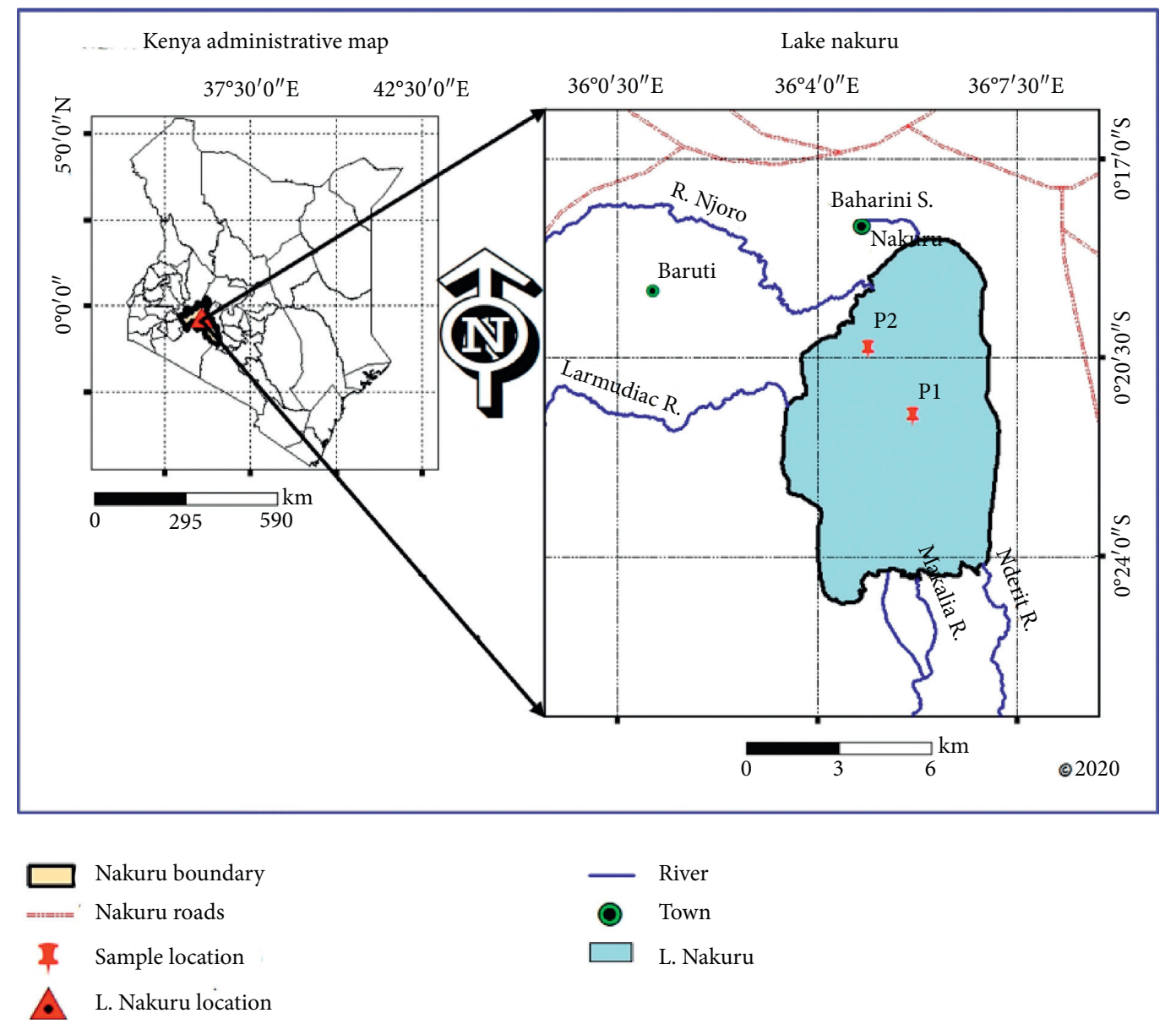

Figure 1: Lake Nakuru location map.

TABLE 1: Sediment core sampling location.

\begin{tabular}{lcr}
\hline Sampling location & Latitude & Longitude \\
\hline P1 & $00^{\circ} 21^{\prime} 33^{\prime \prime} \mathrm{S}$ & $36^{\circ} 05^{\prime} 41^{\prime \prime} \mathrm{E}$ \\
P2 & $00^{\circ} 20^{\prime} 22^{\prime \prime} \mathrm{S}$ & $36^{\circ} 04^{\prime} 54^{\prime \prime} \mathrm{E}$ \\
\hline
\end{tabular}

According to the soil types along the core depth, Lake Nakuru sediment from location P2 presented a high ratio of fine particles at the top of the core. The bottom layers presented a high ratio of sand and a very small ratio of fine particles. The core contained about $50 \%$ of the fine particles, $43 \%$ of sand particles, and $7 \%$ of gravel particles in the $10 \mathrm{~cm}$ layer of the top sediment layer. The ratio of sand increased along the sediment core depth. The sand particles content was about $69 \%$, gravel particles $21 \%$, and $10 \%$ of fine particles in the $10 \mathrm{~cm}$ layer at the sediment core bottom (Figures 3 and 4). Half of the sediment particles contained at the sediment sample top layer was fine particles which included clayey and silty soil. The sand content was $70 \%$ at the sediment bottom. The excessive presence of fine particles in the top layer results in the low soil permeability in the top layer. The soil particle sizes influence the continuity of the pore spaces and the rate of water movement as reported in $[35,41,42]$. According to $[35,39,43]$, the soil porous usually refers to how many pores or holes the soil has. It determines how fast the water enters the soil and the amount of water that a given volume of soil can hold. Then, the finer the particle size, the greater the porosity (Figures 2 and 4).

3.2.2. Sediment Hydrometer Analysis. Results from hydrometer analysis, conducted on sediment core from location $\mathrm{P} 1$, showed that the sediment had an average ratio of $39.38 \%, 34.00 \%$, and $26.63 \%$ of silt, clay, and fine-sand particles, respectively (Figures 5 and 6). It was found that fine particles of silt and clayey nature were approximately $73.38 \%$ of the whole sediment sample. Further, it was observed that the fine particles of the sediment were highly viscous. The presence of small particle size fraction in the soil contributes a lot to the soil plasticity and permeability $[34,39]$. According to $[35,40,43,44]$, a high portion of small-sized pores obstruct the movement or permeability in 


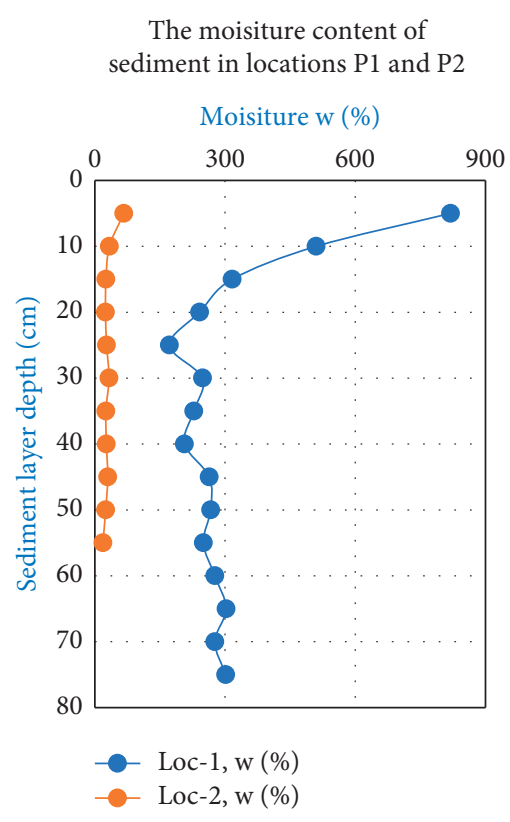

(a)

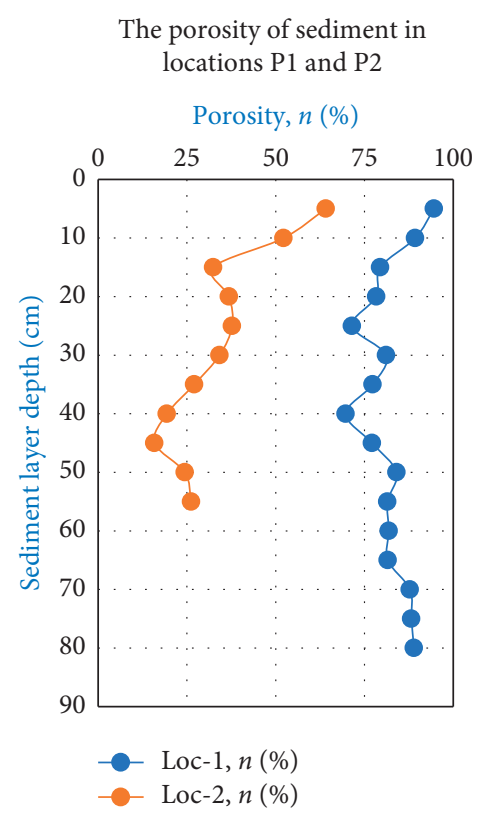

(b)

FIgURE 2: Variation of sediment moisture and porosity along with the core depth.

the porous media. Also, clayey and silty soil fineness allows them to pack together in a certain dense way and leave a high ratio of the small-spaced pores within them, which initiates a closed porosity with a slight water movement. Therefore, from the findings of this study, it was noted that Lake Nakuru sediment from location P1 favours a closed porosity with a slight water movement.

Considering sediment along the core depth, Lake Nakuru sediment from location P1 presented a high ratio of clayey soil particles at the top and bottom of the sediment core. The ratio of clayey soil particles decreased in a third of the core depth with an increase of the ratios of fine-sand and silty soil particles as presented in Figure 6. This shows there is low permeability at the top and an excessive permeability in a third part of the core depth. At $10 \mathrm{~cm}$ layer from top of sediment core, it was observed that the sample contained a ratio of $44 \%, 43 \%$, and $13 \%$ for the clayey, silty, and fine-sand particles, respectively. The ratio of silty and clayey soil particles decreased at the bottom layers of the sediment core with an extent of $42 \%, 38 \%$, and $20 \%$ for the clayey, silty, and fine-sand particles at the layer of $10 \mathrm{~cm}$ at the bottom of the sediment core (Figures 5 and 6). Although the difference in the ratios of silty and clayey soil particles is not very significant, the core presents a substantial amount of clayey soil from the top to the bottom of the sediment core.

The silt and clay soil contained almost $87 \%$ at the top and $80 \%$ at the bottom of the sediment core (Figures 5 and 6 ). The particles size analysis has been reported in $[35,41,42]$ to be crucial for soil hydraulic conductivity analysis. This implies the effect of sediment in decreasing permeability in the top layer of sediment. Therefore, these property changes are considered to be affecting the water seepage in Lake Nakuru.
3.3. Sediment Hydraulic Conductivity. The sediment sample from location P1 presents an insignificant hydraulic conductivity with the maximum permeability coefficient of $3.37 \times 10^{-5} \mathrm{~cm} / \mathrm{s}$ in the bottom layer of the sediment core. The results from experiments showed that the permeability of the sediment sample from location P1 increases along the core depth with the permeability coefficient of $4.71 \times 10^{-6} \mathrm{~cm} / \mathrm{s}$ at the top of the sediment core and $1.67 \times 10^{-5} \mathrm{~cm} / \mathrm{s}$ at the bottom of the sediment core (Figure 7). On the other hand, sediment sample from location P2 presents a high hydraulic conductivity with the minimal permeability coefficient of $4.3 \times 10^{-4} \mathrm{~cm} / \mathrm{s}$ in the top layer of the sediment core. According to the results from experiments done, the permeability of the soil sample from location P2 also increases along with the core depth with the permeability coefficient of $0.001244 \mathrm{~cm} / \mathrm{s}$ at the top of the sediment core and the permeability coefficient of $0.002168 \mathrm{~cm} / \mathrm{s}$ at the bottom of the sediment core (Figure 7). Also, soil permeability was found to be inversely proportional to the moisture and porosity. The higher the water content, the finer the particle size and the less was the hydraulic conductivity (Figures 2 and 7). According to $[40,44,45]$, the soil permeability is a primal aspect for the sediment physical properties that reflect the water seepage. It is basic analysis for the water movement and the flow rate formation of the sediment at the lake bed level.

From the results, both hydraulic conductivity of the sediment sample from location P1 and P2 increased along with the core depth; this confirmed the influence of sediment in the water balance and water level rise due to the decreases of water movement in the top layers of sediment from Lake Nakuru. 
Grading chart - sample location P2 (0-55) cm

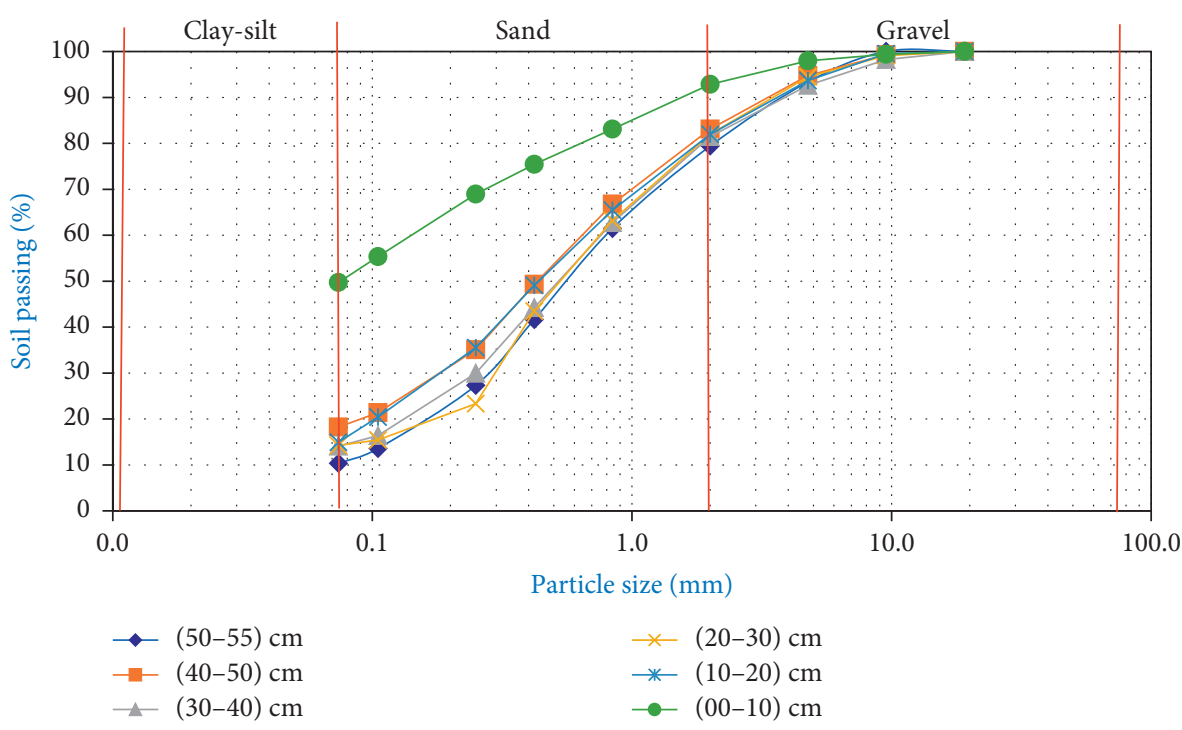

Figure 3: The sieve analysis grading curves of the sample from location P2.

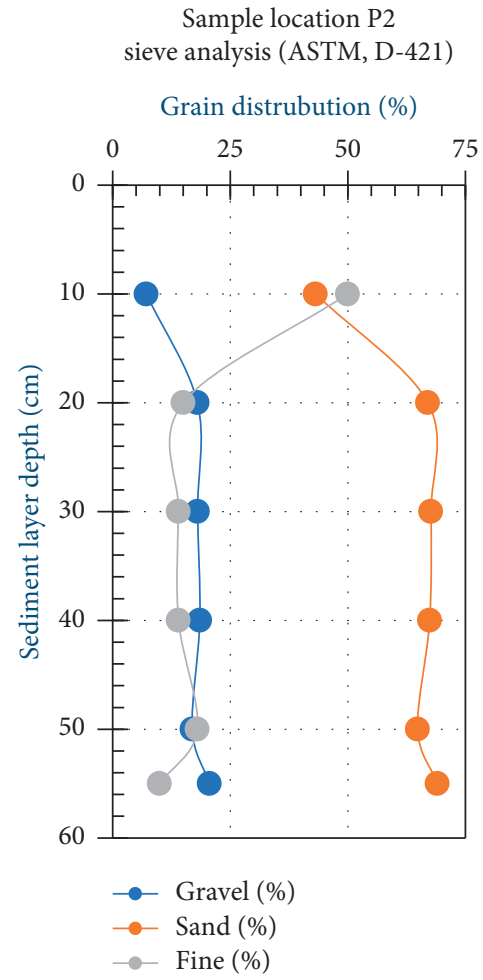

FIgURE 4: Sieve analysis ratio of the sediment soil types along with the core depth. 


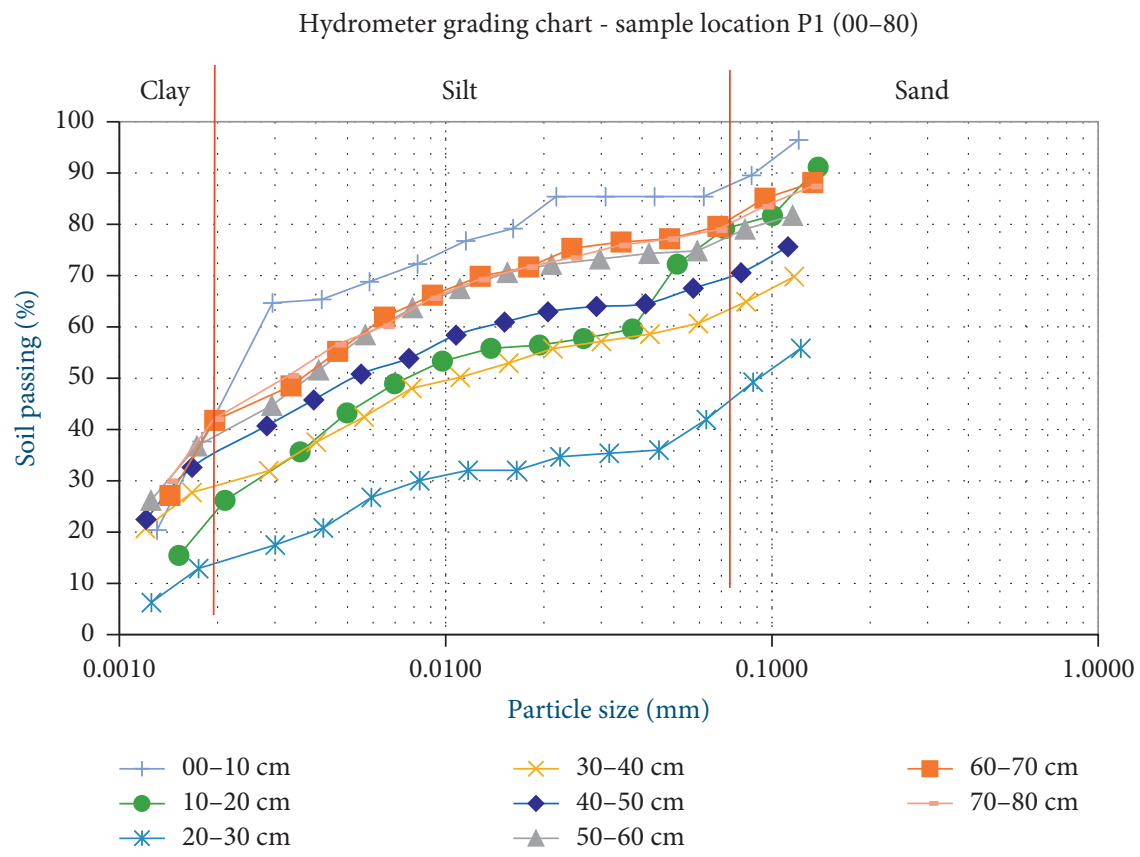

FIGURE 5: Hydrometer analysis grading curves of the sample from location P1.

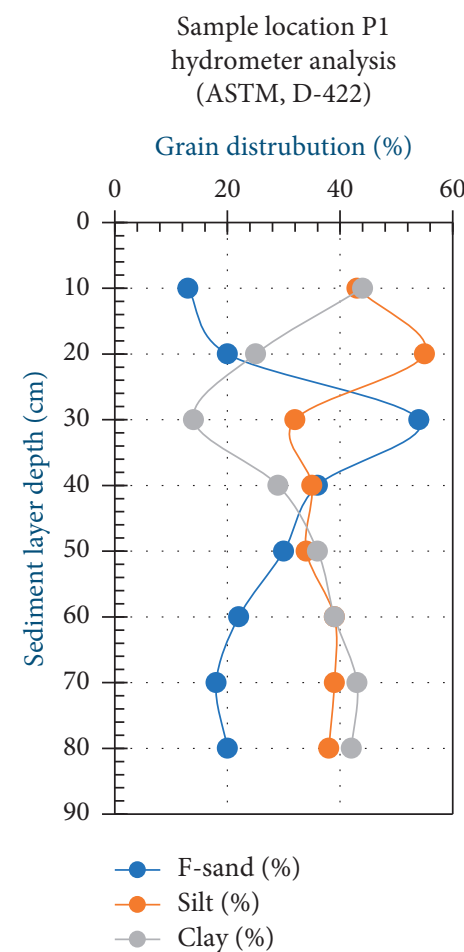

FIGURE 6: Hydrometer analysis ratio of the sediment soil types along with the core depth. 


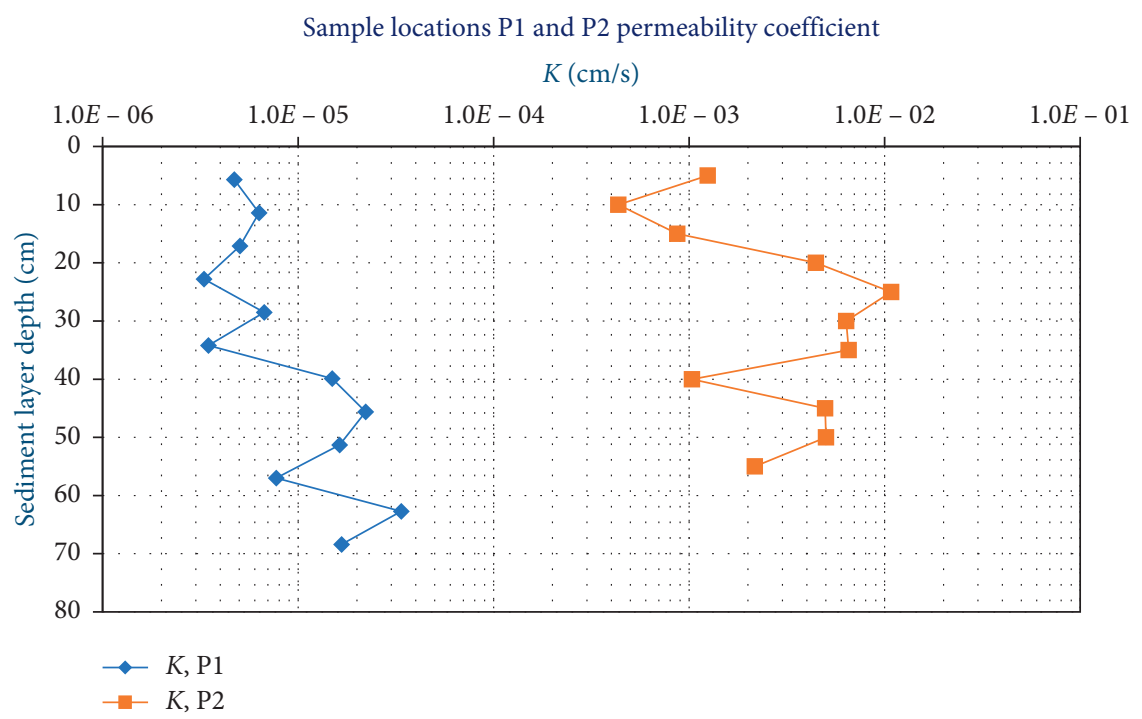

FIgURe 7: Hydraulic conductivity of sediment from locations P1 and P2.

\section{Conclusions and Recommendations}

The sediment core from location P1 had more than $800 \%$ water content at the top which decreased along the core with bottom of sediment core having about $300 \%$ water content. The sediment core from location P2 was found to have lesser than $80 \%$ water content. Therefore, the soil permeability was inversely proportional to the water content. The higher was the water content, the lesser the soil could be permeable.

The sediment sample from location P1 had an average ratio of $39.38 \%, 34.00 \%$, and $26.63 \%$ for silty, clayey, and fine-sand soil particles, respectively. The sediment core also had maximum permeability coefficient of $3.37 \times 10^{-5} \mathrm{~cm} / \mathrm{s}$. Considering the sediment core from location P2, an average of $63.17 \%$ for sand, $20.17 \%$ for fine particles, and $16.67 \%$ for gravels was observed with the maximum permeability coefficient of $0.010793 \mathrm{~cm} / \mathrm{s}$. The hydraulic conductivity of sediment sample from both locations P1 and P2 increased along with the core depth, which implies the influence of sediment in the water level rises due to the decreases of water movement in the top layers of sediment.

According to the results of hydraulic properties for the sediment accumulated in Lake Nakuru, the sediment deposited on the lake bed level affects the water seepage. The water movement at the bed level decreases as the sediments are filling in the lake. This could negatively affect the lake water balance where there could be a lake water level rise. Hence, there is a need to control the inflow of sediment from the watershed. Further study on the hydrometeorological and groundwater monitoring to analyse the climate changes in the lake drainage basin and the lake's water balance by focusing on the issue of the rising of water level from the past 50 years is recommended.

\section{Data Availability}

The data used to support the study are shared in the Supplementary Information files submitted alongside the manuscript. They can also be made available on request from the corresponding author through the e-mail: mugemalixparfait@gmail.com.

\section{Conflicts of Interest}

The authors declare no conflicts of interest regarding the publication of this article.

\section{Acknowledgments}

The authors are thankful to Jomo Kenyatta University of Agriculture and Technology (JKUAT) and Pan African University, Institute of Science Technology and Innovation (PAUSTI), for all support provided for this research study. The authors honour the assistance given by Joseph Sang and Caroline Maina for the entire period of the study. Furthermore, the authors appreciate the assistance and accessing permission given by the Kenya Wildlife Service (KWS) and Managing Board of Lake Nakuru National Park (LNNP).

\section{Supplementary Materials}

Lab experiments were used to evaluate the hydraulic properties of sediment. The datasets used were recorded and processed in different spreadsheets based on each type of experiment. (1) The moisture and porosity were used to analyse the properties related to the water seepage. The infiltration rate of soil also depends on pore space in the soil porous media which reflect the moisture and porosity in the sample. Eleven to sixteen experiments were done from the top to the bottom of each core, within an interval of $5 \mathrm{~cm}$. (2) Particle size analysis was used in analysing the implication of soil texture in the water seepage. The analysis complied of sieve analysis and hydrometer analysis was done to the sediment sample from locations P1 and P2, respectively. Six to eight experiments were done from the top to the bottom of each 
core, within an interval of $10 \mathrm{~cm}$. (3) Hydraulic conductivity was used in analysing the physical properties of sediment that reflects the water movement and the flow rate formation of the sediment at the lake bed level. Eleven to twelve experiments were done from the top to the bottom of each core, within an interval of 5 to $10 \mathrm{~cm}$. (Supplementary Materials)

\section{References}

[1] J. C. Osuagwu, A. N. Nwachukwu, H. U. Nwoke, and K. C. Agbo, "Effects of soil erosion and sediment deposition on surface water quality: a case study of Otamiri river," Asian Journal of Engineering and Technology, vol. 2, no. 5, pp. 438-442, 2014.

[2] M. Shafai Bajestan, H. Mohammad Vali Samani, E. Valizadegan, M. Shafaei Bajestan, and H. Mohammad Vali Samani, "Control of sedimentation in reservoirs by optimal operation of reservoir releases sensitivity analysis of effective factors on nonadherent sediment transportation in inverted siphon by utilizing mlp model view project machine learning view project control," 2005, http://www.world-food.net.

[3] A. Mulu and G. S. Dwarakish, "Different approach for using trap efficiency for estimation of reservoir sedimentation. An overview," Aquatic Procedia, vol. 4, pp. 847-852, 2015.

[4] G. W. Annandale, G. L. Morris, and P. Karki, Extending the Life of Reservoirs: Sustainable Sediment Management for Dams and Run-of-River Hydropower, The World Bank, Washington, DC, USA, 2016.

[5] C. Brown, J. Stall, and E. DeTurk, The Causes and Effects of Sedimentation in Lake DecaturIllinois State Water Survey, Urbana, IL, USA, October 2020, https://www.ideals.illinois. edu/bitstream/handle/2142/94561/ISWSB-37.pdf? sequence $=1$.

[6] C. Maina-Gichaba, W. A. Shivoga, E. M. Enanga, S. Kibichii, and S. N. Miller, "Sediment loading on inland lakes/wetlands: a case study of lake Nakuru, Kenya," in Proceedings of the 11th World Lakes Conference, vol. 2, pp. 389-391, October 2005, https://www.ilec.or.jp/wp-content/uploads/wlc/wlc11/wlc11_ Proceedings_2.pdf.

[7] M. W. Jenkins, S. McCord, and J. Edebe, Sustaining Lake Levels in Lake Nakuru, Kenya: Development of a Water Balance Model for Decision Making, Global Livestock CRSP, University of California-Davis, Davis, CA, USA, 2009.

[8] R. Becht, F. Mwango, and F. A. Muno, "Groundwater links between Kenyan rift valley lakes," in Proceedings of the 11th World Lakes Conference, pp. 7-14, Nairobi, Kenya, October 2005.

[9] D. Olago, A. Opere, and J. Barongo, "Holocene palaeohydrology, groundwater and climate change in the lake basins of the Central Kenya Rift," Hydrological Sciences Journal, vol. 54, no. 4, pp. 765-780, 2009.

[10] W. G. Arling, D. J. Allen, and J. C. Talbot, "Water balance of lakes in the Kenya Rift Valley," in Proceedings of an International Symposium on Isotope Techniques in Water Resources Development, pp. 733-735, The International Atomic Energy Agency (IAEA), Vienna, Austria, March 1991.

[11] W. G. Darling, B. Gizaw, and M. K. Arusei, "Lake-groundwater relationships and fluid-rock interaction in the east African rift valley: isotopic evidence," Journal of African Earth Sciences, vol. 22, no. 4, pp. 423-431, 1996.

[12] W. G. Darling, D. J. Allen, and H. Armannsson, "Indirect detection of subsurface outflow from a rift valley lake," Journal of Hydrology, vol. 113, no. 1-4, pp. 297-306, 1990.
[13] P. Iradukunda, J. K. Sang, M. O. Nyadawa, and C. W. Maina, "Sedimentation effect on the storage capacity in lake Nakuru, Kenya," Journal of Sustainable Research in Engineering, vol. 5, no. 3, pp. 149-158, 2020.

[14] E. O. Odada, J. Raini, and R. Ndetei, "Lake Nakuru: experience and lessons learned brief," Lake Basin Management Initiative: Main Report, pp. 299-321, University of Nairobi Research Archive, Nairobi, Kenya, 2006.

[15] A. N. Kimaru, J. M. Gathenya, and C. K. Cheruiyot, "The temporal variability of rainfall and streamflow into Lake Nakuru, Kenya, assessed using SWAT and hydrometeorological indices," Hydrology, vol. 6, no. 4, p. 88, 2019.

[16] E. Vareschi, "The ecology of Lake Nakuru (Kenya) I abundance and feeding of the lesser flamingo," Oecologia, vol. 32, no. 1, pp. 11-35, 1978.

[17] E. Vareschi, “The ecology of Lake Nakuru (Kenya): II biomass and spatial distribution of fish (Tilapia grahami Boulenger = Sarotherodon alcalicum grahami Boulenger)," Oecologia, vol. 37, no. 3, pp. 321-335, 1979.

[18] E. Vareschi, "The ecology of Lake Nakuru (Kenya): III abiotic factors and primary production," Oecologia, vol. 55, no. 1, pp. 81-101, 1982.

[19] E. Vareschi and A. Vareschi, "The ecology of Lake Nakuru (Kenya): IV biomass and distribution of consumer organisms," Oecologia, vol. 61, no. 1, pp. 70-82, 1984.

[20] E. Vareschi and J. Jacobs, "The ecology of Lake Nakuru (Kenya) V production and consumption of consumer organisms," Oecologia, vol. 61, no. 1, pp. 83-98, 1984.

[21] E. Vareschi and J. Jacobs, "The ecology of Lake Nakuru: VI synopsis of production and energy flow," Oecologia, vol. 65, no. 3, pp. 412-424, 1985.

[22] M. B. Abbott and L. Anderson, "Lake-level fluctuations," in Encyclopedia of Earth Sciences Series, pp. 489-492, Springer, Dordrecht, Netherlands, 2009.

[23] K. Szesztay, "Water balance and water level fluctuations of lakes," Hydrological Sciences Bulletin, vol. 19, no. 1, pp. 73-84, 1974.

[24] S. Agembe, W. Ojwang, C. Olilo, R. Omondi, and C. Ongore, "Soda lakes of the rift valley (Kenya)," in The Wetland Book, pp. 1-11, Springer, Dordrecht, Netherlands, 2016.

[25] F. Jirsa, M. Gruber, A. Stojanovic et al., "Major and trace element geochemistry of Lake Bogoria and Lake Nakuru, Kenya, during extreme draught," Geochemistry, vol. 73, no. 3, pp. 275-282, 2013.

[26] M. Leichtfried and W. Shivoga, "The Njoro river-lake Nakuru ecotonal system in Kenya," Jber. Biol. Stn Lunz, vol. 15, pp. 67-77, 1995.

[27] V. E. Smith, J. E. Rathbun, S. G. Rood, and L. L. Huellmantel, "Technical considerations in sediment quality surveys," Journal of Great Lakes Research, vol. 22, no. 3, pp. 512-522, 1996.

[28] J. A. Dunbar, P. M. Allen, and P. D. Higley, "Multifrequency acoustic profiling for water reservoir sedimentation studies," Journal of Sedimentary Research, vol. 69, no. 2, pp. 518-527, 1999.

[29] C. W. Maina, J. K. Sang, J. M. Raude, and B. M. Mutua, "Geochronological and spatial distribution of heavy metal contamination in sediment from Lake Naivasha, Kenya," Journal of Radiation Research and Applied Sciences, vol. 12, no. 1, pp. 37-54, 2019.

[30] H. Adachi, H. Yamano, T. Miyajima, and M. Nakaoka, "A simple and robust procedure for coring unconsolidated sediment in shallow water," Journal of Oceanography, vol. 66, no. 6, pp. 865-872, 2010.

[31] D. E. Lanesky, B. W. Logan, R. G. Brown, and A. C. Hine, "A new approach to portable vibracoring underwater and on 
land," Journal of Sedimentary Research, vol. 49, no. 2, pp. 654-657, 1979.

[32] C. G. Ingersoll and D. D. MacDonald, A Guidance Manual to Support the Assessment of Contaminated Sediments in Freshwater Ecosystems-Volume III-Interpretation of the Results of Sediment Quality Investigations, U.S. EPA Great Lakes National Program, Chicago, IL, USA, 2002.

[33] B. N. Maclver, G. P. Hale, R. A. Barron, M. M. Johnston, and R. W. Beene, Engineering and Design Manual: Laboratory Soils Testing, United States Army Corps of Engineers, Waterways Experiment Station (WES), Washington, DC, USA, 1986.

[34] B. M. Das, Soil Mechanics Laboratory Manual, Oxford University Press, New York, NY, USA, 6th edition, 2002.

[35] T. W. Lambe and R. V. Whitman, Soil Mechanics, John Wiley \& Sons Inc., New York, NY, USA, 1969.

[36] ASTM D5084-10, "Standard Test Methods for Measurement of Hydraulic Conductivity of Saturated Porous Materials Using a Flexible Wall Permeameter," ASTM, West Conshohocken, PA, USA, 2010.

[37] S. Irmay, "On the hydraulic conductivity of unsaturated soils," Transactions, American Geophysical Union, vol. 35, no. 3, pp. 463-467, 1954.

[38] P. C. Carman, "Permeability of saturated sands, soils and clays," The Journal of Agricultural Science, vol. 29, no. 2, pp. 262-273, 1939.

[39] USDA, Engineering Field Manual, United States Department of Agriculture, Soil Conservation Service, Washington, DC, USA, 1990.

[40] N. Ebrahimi-Birang, "The hydraulic behaviour of sand and silt soils around the residual-state condition," $\mathrm{Ph}$. D. Thesis, University of Saskatchewan, Saskatoon, Canada, 2012.

[41] J. Rosas, O. Lopez, T. M. Missimer et al., "Determination of hydraulic conductivity from grain-size distribution for different depositional environments," Groundwater, vol. 52, no. 3, pp. 399-413, 2014.

[42] Z. Zięba, "Influence of soil particle shape on saturated hydraulic conductivity," Journal of Hydrology and Hydromechanics, vol. 65, no. 1, pp. 80-87, 2017.

[43] T. Dutta and S. Tarafdar, "Fractal pore structure of sedimentary rocks: simulation by ballistic deposition," Journal of Geophysical Research: Solid Earth, vol. 108, no. 2, pp. 1-6, 2003.

[44] A. Basile, G. Mele, and F. Terribile, "Soil hydraulic behaviour of a selected benchmark soil involved in the landslide of Sarno 1998," Geoderma, vol. 117, no. 3-4, pp. 331-346, 2003.

[45] S. Hu, H. Zhu, and Y. Chen, "One-dimensional horizontal infiltration experiment for determining permeability coefficient of loamy sand," Journal of Arid Land, vol. 9, no. 1, pp. 27-37, 2017. 